\title{
ADDITIONS TO CLASSICAL SEQUENCE OF PLEISTOCENE GLACIATIONS, SIERRA NEVADA, CALIFORNIA
}

\begin{abstract}
Two additions are proposed to Blackwelder's classical sequence of four Pleistocene glaciations (Tioga, Tahoe, Sherwin, and McGee) of the Sierra Nevada. The younger, the Tenaya, lies between Tioga and Tahoe, giving a three-fold subdivision of the Wisconsin. The older, named
\end{abstract}

\section{Introduction}

In 1931 Eliot Blackwelder published his classical paper on Pleistocene glaciation in the Sierra Nevada of California. This work established the sequence of Tioga, Tahoe, Sherwin, and McGee glaciations that for 30 years has served as a principal datum of reference for Pleistocene continental events in the farwestern United States. Blackwelder (1931, p. 870) explicitly recognized that subsequent studies would probably produce modifications of this succession. That the sequence has endured for so long without major alteration is a tribute to the soundness of his work. The changes proposed herein are additions rather than alterations.

Investigations during the past decade provide evidence for two additional phases of glaciation in the Sierra Nevada. The first is Wisconsin, occurring between Tioga and Tahoe, for which the name Tenaya ${ }^{1}$ has been proposed (Birman, in press). The second is a glaciation, possibly Illinoian, that occurred between the Tahoe and Sherwin, herein named Mono Basin. Comparison of the old and revised sequences is shown in Table 1. Identifications as Wisconsin, Illinoian, Kansan, and Nebraskan are suggestive only.

This brief presentation is offered in order to obtain critical scrutiny by investigators working with California Pleistocene events. Details of relationships and semiquantitative data that led to recognition of the additional

1 The initial name, Graveyard (Birman, 1957. Ph.D. thesis, Univ. of Calif. at Los Angeles, p. 55; Putman, 1962 , p. 198), has been replaced by the more appropriate designation, Tenaya.
Mono Basin, fills the long-recognized gap between Tahoe and Sherwin; it is possibly Illinoian. Evidence for the Mono Basin glaciation is scanty because its ice streams were less extensive than the subsequent Tahoe glaciers.

glacial phases will have to await publication of more extensive works, one of which is due in the fall of 1963 (Birman, in press).

\section{Tenaya Glaciation}

The two most easily distinguished of Blackwelder's eastern Sierra Nevada glaciations are Tioga and Tahoe. They can be quickly identi-

Table 1. Comparison of Glacial Sequences

\begin{tabular}{lcl}
\hline $\begin{array}{c}\text { Suggested } \\
\text { correlation with } \\
\text { continental sequence }\end{array}$ & $\begin{array}{c}\text { Blackwelder } \\
(1931, \text { p. 918) }\end{array}$ & This paper \\
\hline Wisconsin & $\left\{\begin{array}{l}\text { Tioga } \\
\text { Tahoe }\end{array}\right.$ & $\begin{array}{l}\text { Tioga } \\
\text { Tenaya } \\
\text { Tahoe }\end{array}$ \\
Illinoian & $\ldots$ & $\begin{array}{l}\text { Mono Basin } \\
\text { Kansan }\end{array}$ \\
Nebraskan & Sherwin & McGee \\
\hline
\end{tabular}

fied by experienced workers in most east-slope glaciated canyons (Fig. 1). During 1950-1952 while mapping glacial deposits in Vermilion Valley (Fig. 2), tributary to the South Fork of the San Joaquin River on the western Sierra Nevada slope, Birman (1954; 1959) found evidence for a glaciation between Tioga and Tahoe. In subsequent studies he traced this three-fold subdivision of the Wisconsin (Table 1) across the Sierra Nevada crest into the drainage of Rock Creek, an east-slope stream. Subsequently, Birman made reconnaissance investigations of strongly glaciated east-slope canyons, specifically Lee Vining, Rush, and Pine creeks, and found in all evidence of a glaciation intermediate between

Geological Society of America Bulletin, v. 74, 1079-1086, 3 figs., August 1963 
Tioga and Tahoe. The name Tenaya has been proposed for this glacial phase (Birman, in press). Sharp, working in the Bridgeport Basin (Fig. 1) in 1960-1962, accumulated further evidence for the Tenaya in that area. separate ridge between Tioga and Tahoe laterals. Such situations provide some of the best evidence for the Tenaya glaciation. Moraines now mapped as Tenaya were included within the Tioga or Tahoe by earlier workers.

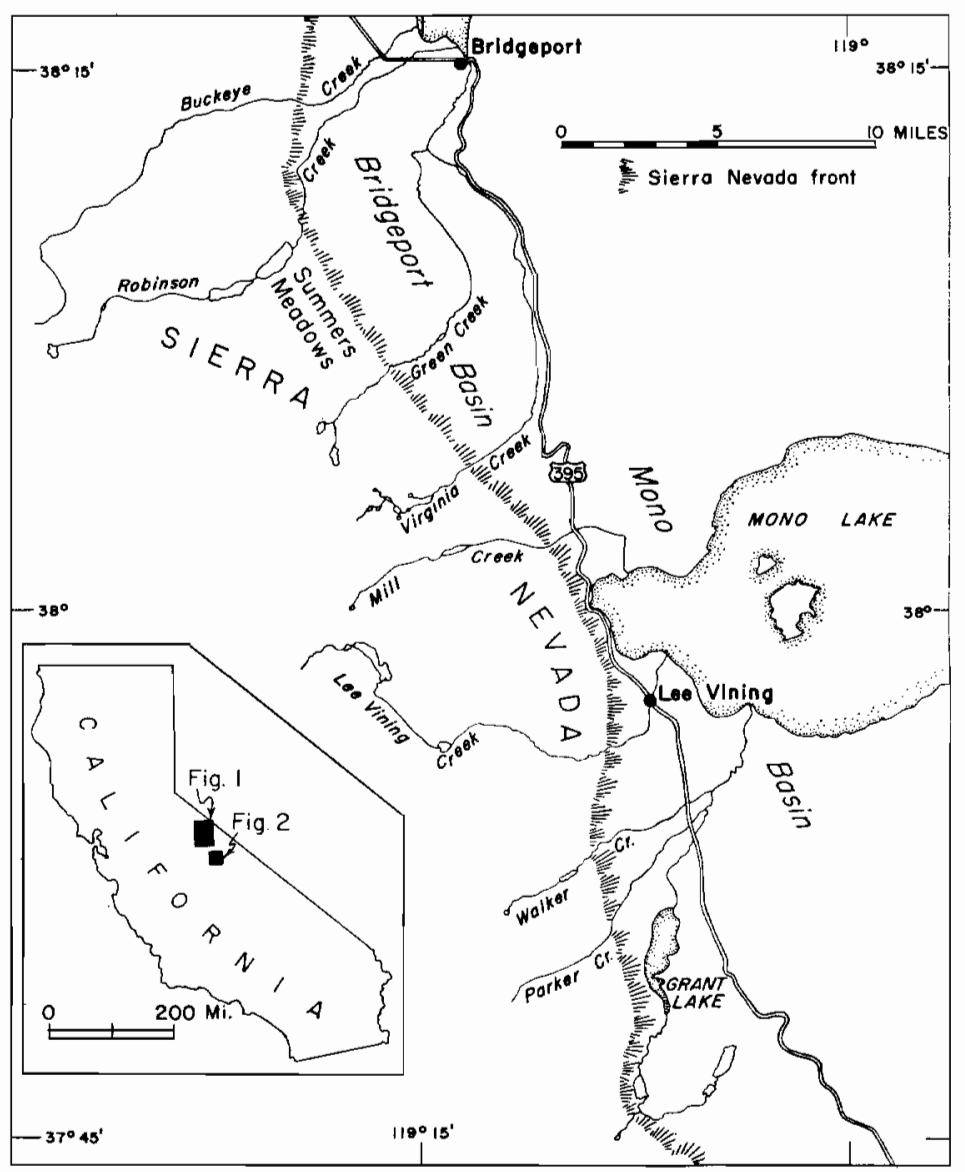

Figure 1. Pertinent localities in Bridgeport and Mono basins, Sierra Nevada, California

Recognition of the Tenaya glaciation came slowly because its ice streams, intermediate in length between Tioga and Tahoe, did not build massive end moraines, and being widely breached by axial streams they are easily overlooked in the complex of massive Tioga end moraines and huge bordering Tahoe laterals. Furthermore, the Tenaya laterals, except in their outermost reaches, are mostly overtopped by the Tioga. Where this does not occur, the Tenaya constitutes a distinctly
Tenaya moraines are distinctly fresher, sharper, and topographically more ragged than Tahoe. On Robinson Creek in Bridgeport Basin, Tenaya moraines pass under the Tioga terminal loop with a distinct topographic unconformity. Identification of the Tenaya as a separate and distinct glacial phase is further supported by semiquantitative data. Birman has made many granitic boulder-weathering counts on closely associated Tioga, Tenaya, and Tahoe moraines of comparable setting and 
lithologic constitution (Table 2). Additional evidence of the age difference between Tioga, Tenaya, and Tahoe glaciations collected by Sharp is compiled in Tables 3-5.

Recognition of the Tenaya results in a threefold subdivision of the Wisconsin in the Sierra Nevada, if the practice of regarding Tioga and Tahoe as Wisconsin is accepted. Nothing discovered during this study provides a basis for correlating the Tenaya specifically with a particular phase of Wisconsin continental glaciation. However, three phases of Wisconsin ice advance agree with modern interpretations of North American continental ice-sheet behavior (Frye and Willman, 1960, p. 2). Moreover, the three mud layers in Searles Lake and the $\mathrm{C}^{14}$ dates reported there by Smith (1962, p. 66) support a threefold subdivision of the Wisconsin as does the sequence of Lake Lahontan beds and dates in Truckee Canyon (Broecker and Orr, 1958, p. 1019-1020).

Good Tenaya moraines can be seen on

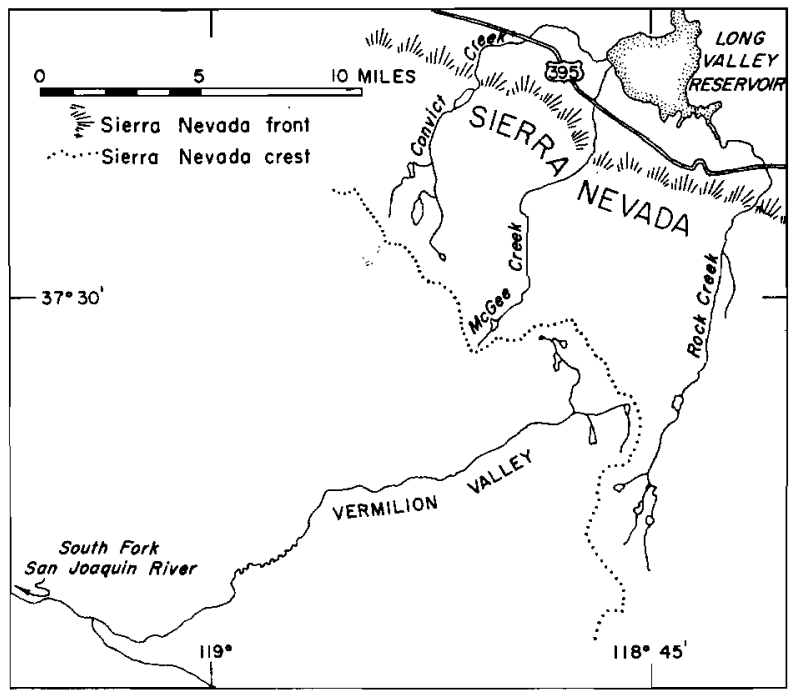

Figure 2. Vermilion Valley, Rock Creek area, Sierra Nevada, California

Table 2. Median Ratio Values for Per Cent Weathered* to Per Cent Unweathered Granitic Boulders in Sierra Nevada Wisconsin Moraines

\begin{tabular}{|c|c|c|c|}
\hline & Glaciation & $\begin{array}{l}\text { Sequoia-King's } \\
\text { Canyon } \\
\text { National Parks }\end{array}$ & $\begin{array}{l}\text { San Joaquin } \\
\text { River drainage, } \\
\text { Yosemite and } \\
\text { eastern slope } \\
\text { of Sierra Nevada }\end{array}$ \\
\hline \multirow{3}{*}{ 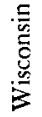 } & Tioga & $30 / 70 \quad(42)^{\dagger}$ & $30 / 70 \quad(51)$ \\
\hline & Tenaya & $51 / 49 \quad(48)$ & $49 / 51 \quad(47)$ \\
\hline & Tahoe & $73 / 27$ & $67 / 33 \quad(35)$ \\
\hline
\end{tabular}

* A boulder was classed as fresh if more than half its surface had not been roughened by a weathering penetration to the depth of the average grain diameter. Weathered boulders have surfaces roughened or made crumbly by deeper weathering.

Total number of locality counts in parentheses
Walker (laterals and partial loops) and Lee Vining (laterals) creeks in Mono Basin and on Green (laterals) and Robinson (lateral and partial loops) creeks in Bridgeport Basin (Fig. 1).

\section{Mono Basin Glaciation}

Blackwelder (1931, p. 870, 918-919) predicted that an additional glaciation might eventually be recognized within the long interval between Sherwin (Kansan) and Tahoe (early Wisconsin). He noted scanty evidence for such an event and inferred that many of its features had been obliterated by later ice advances.

According to our interpretations, this is correct. Ice streams of the Mono Basin glaciation flowing down canyons on the east slope of the Sierra Nevada were less extensive than 
Table 3. Comparative Data on Lateral Moraines in Bridgeport Basin

\begin{tabular}{lccc}
\hline \hline $\begin{array}{c}\text { Number of boulders } \\
\text { greater than } 1 \mathrm{ft} . \\
\text { diameter in } 100 \times 20 \text {-ft. } \\
\text { strip }\end{array}$ & $\begin{array}{c}\text { Gruss/stone ratio by } \\
\text { estimated per cent of } \\
\text { ground area covered }\end{array}$ & $\begin{array}{c}\text { Ratio of per cent } \\
\text { granitic to per cent } \\
\text { metamorphic stones }\end{array}$ \\
\hline East Side Robinson Creek at Upper Summers Meadows & \\
Tioga & 200 & $15 / 85$ & $\ldots$ \\
Tenaya & 160 & $50 / 50$ & $\ldots$ \\
Tahoe & 60 & $85 / 15$ & $\ldots$ \\
& & East of Green Creek & \\
Tioga & 310 & $20 / 80$ & $60 / 20$ \\
Tenaya & 135 & $50 / 50$ & $30 / 70$ \\
Tahoe & 95 & $75 / 25$ & 30 \\
\hline
\end{tabular}

those of the subsequent Tahoe advance. Thus, evidence of this earlier glaciation was destroyed or obscured except in those instances where the later ice streams followed a different path. Kesseli (1941, p. 327) called attention to the potential value of such geometrical relationships in distinguishing separate glaciations. The name, Mono Basin, is proposed for this glaciation intermediate between Tahoe and Sherwin since some of the best evidence is along streams tributary to that basin.

During this work, inklings of a glaciation intermediate between Tahoe and Sherwin were first obtained from the lithology of large granitic erratics in the Summers Meadows area of Bridgeport Basin (Fig. 1). These erratics were derived from Robinson Creek and were transported in pre-Tahoe time by ice out of Robinson Creek moving eastward through Summers Meadows. It is not known whether this occurred instead of, or in addition to, the flow of ice northward along the present course of lower Robinson Creek which was followed exclusively by the Tahoe and subsequent glaciers. Initially, the Summers Meadows glacial debris was regarded as entirely Sherwin, but more study suggested that deposits of a post-Sherwin pre-Tahoe glaciation were also present.

This conclusion led to a search for other situations where Tahoe and later glaciers followed paths different from those of earlier ice streams. Thoughts naturally turned to the unusual and well-documented morainal relationships on lower Walker Creek (Bloody Canyon) in Mono Basin (McGee, 1885, p. 388; Russell, 1889, p. 339; Kesseli, 1941, p. 327; Putnam, 1949, p. 1291). Walker Creek displays one of the most clean-cut and spectacular sets of lateral moraines of the east

Table 4. Hole-In-The-Ground Comparisons of Tioga, Tenaya, and Tahof. Moraines in Bridgeport Basin*

\begin{tabular}{|c|c|c|c|c|c|c|}
\hline \multirow[b]{2}{*}{ Glaciation } & \multicolumn{2}{|c|}{ Weight per cent coarse grains } & \multicolumn{2}{|c|}{ Weight per cent medium grains } & \multicolumn{2}{|c|}{ Weight per cent fine grains } \\
\hline & $\begin{array}{c}\text { First } \\
\text { increment }\end{array}$ & $\begin{array}{l}\text { Second } \\
\text { increment }\end{array}$ & $\begin{array}{c}\text { First } \\
\text { increment }\end{array}$ & $\begin{array}{l}\text { Second } \\
\text { increment }\end{array}$ & $\begin{array}{c}\text { First } \\
\text { increment }\end{array}$ & $\begin{array}{l}\text { Second } \\
\text { increment }\end{array}$ \\
\hline \multicolumn{7}{|c|}{ Lateral Moraines of Robinson Creek at Upper Summers Meadows } \\
\hline Tioga & 78 & 65 & 5 & 10 & 17 & 26 \\
\hline Tenaya & 44 & 44 & 25 & 26 & 32 & 31 \\
\hline Tahoe & 23 & 17 & 32 & 36 & 46 & 48 \\
\hline \multicolumn{7}{|c|}{ East Side Lateral Moraines of Green Creek } \\
\hline Tioga & 31 & 34 & 28 & 23 & 41 & 43 \\
\hline Tenaya & 20 & 12 & 35 & 40 & 45 & 49 \\
\hline Tahoe & 14 & 4 & 33 & 47 & 53 & 49 \\
\hline
\end{tabular}

* The hole-in-the-ground method involves field screening of two successively deeper increments of debris from a shallow hole on the crest of a moraine. In evaluating the results, it is more important to focus upon variations in the values cited than upon the magnitude of these values. 

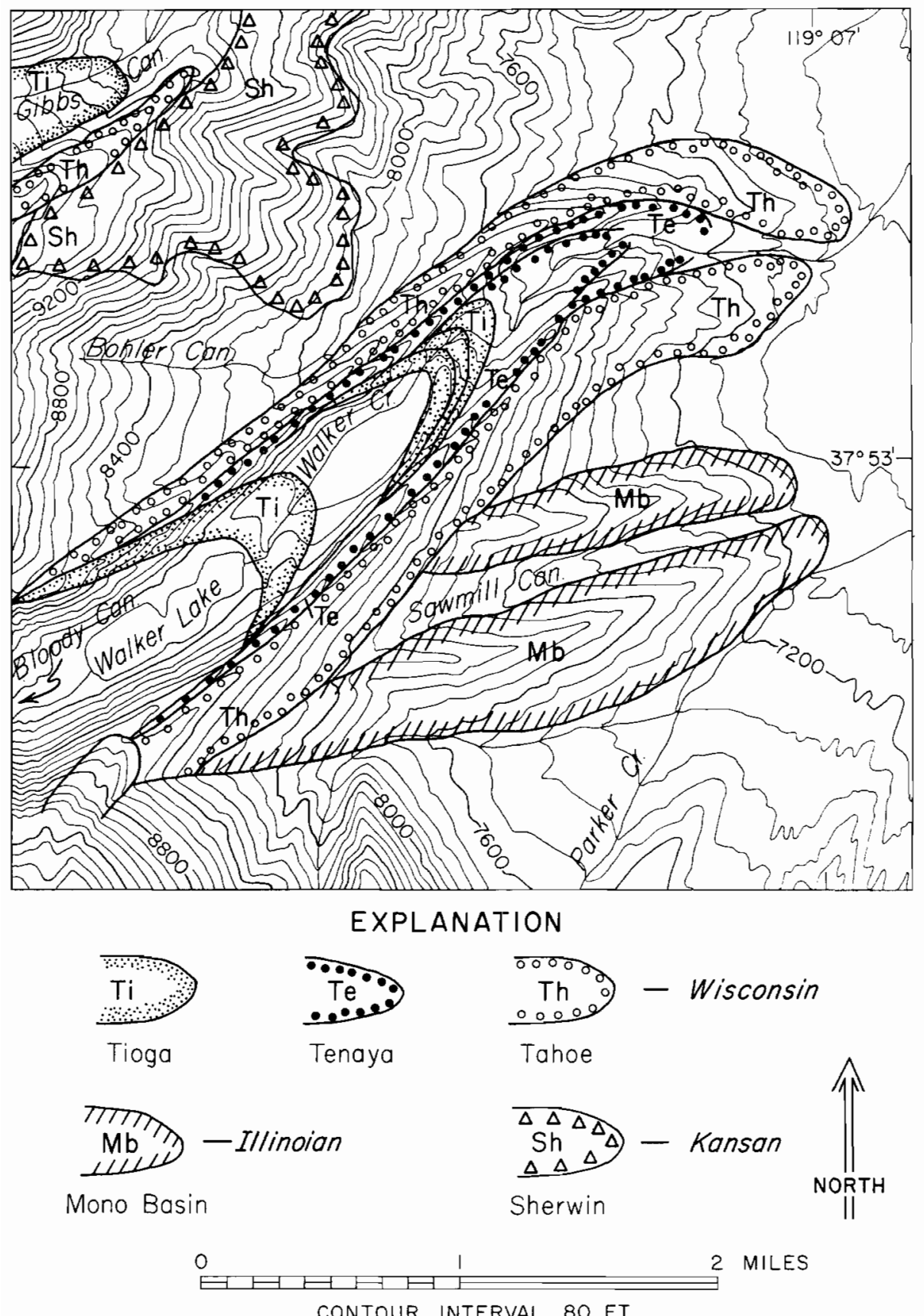

Figure 3. Moraines of Walker Creek (Bloody Canyon) in Mono Basin, Sierra Nevada, California 
Sierra slope. Most unusual are the two large lateral moraines, inclosing Sawmill Canyon, that diverge from the present course of lower Walker Creek. They lie outside of the large right-side Tahoe lateral of Walker Creek and project eastward from it at an angle of about $30^{\circ}$ (Fig. 3). The topographic-geometrical relationship and the lithologic constitution of these moraines show clearly that they are the product of an ice stream that descended from Bloody Canyon (upper Walker Cteek) but followed a more easterly course across the nam, 1949, Fig. 1; Pl. 3, 7). In this area, at least, the topography of the mountain front and of the piedmont seems to have been considerably different during the Sherwin than during the Mono Basin and subsequent glaciations.

A search of other canyons in which Tahoe and later ice streams followed a course divergent from that of Mono Basin glaciers should reveal evidence of this earlier glaciation. Study of two morainal ridges high on the south side of Mill Creek in Lundy Canyon

Table 5. Comparative Data, Walker Creek (Bloody Canyon) Moraines, Mono Basin

\begin{tabular}{lcccc}
\hline \hline $\begin{array}{c}\text { Number of } \\
\text { boulders over } \\
1 \mathrm{ft} \text {. diameter in } \\
100 \times 20 \text {-ft. strip* }\end{array}$ & $\begin{array}{c}\text { Gruss/stone } \\
\text { ratio by estimated } \\
\text { per cent area of } \\
\text { coverage on surface }\end{array}$ & $\begin{array}{c}\text { Ratio of per cent } \\
\text { granitic to per cent } \\
\text { "resistate" stones } \\
\text { over 0.5 ft. diameter }\end{array}$ & $\begin{array}{c}\text { Ratio of per cent } \\
\text { weathered to per } \\
\text { cent unweathered } \\
\text { boulders }\end{array}$ \\
\hline Tioga & 300 & $10 / 90$ & & $10 / 90$ \\
Tenaya & 180 & $30 / 70$ & $50 / 50$ & $50 / 50$ \\
Tahoe & 115 & $50 / 50$ & $29 / 71$ & $80 / 20$ \\
Mono & 60 & $90 / 10$ & $17 / 83$ & $95 / 5$ \\
\hline
\end{tabular}

* Composite of several counts

$\dagger$ "Resistates" are mostly fine-grained metamorphic and fine-grained igneous rocks that weather much less readily than the typical medium-coarse-grained granodioritic Sierra Nevada rocks. Usually at least 200 stones counted

** Unweathered boulders are taken as those which have a major portion of their worn predepositional surfaces preserved. Weathered boulders are the opposite.

piedmont slope than that taken by the Tahoe and later glaciers. It is also clear that these moraines would have been overwhelmed by the longer Tahoe glacier if it had followed the same course. These features are clearly visible to travellers on U. S. Highway 395 and are well shown on the Mono Craters, California, U. S. Geological Survey topographic quadrangle of 1953 and on W. D. Johnson's map of 1887 (Russell, 1889, p. 340).

That the Tahoe laterals are superimposed across the upper ends of the abandoned moraines of Sawmill Canyon is adequate testimony to a considerable age difference. Further evidence is given by data summarized in Table 5. It is for these reasons that the Mono Basin glaciation is not regarded as an early phase of the Tahoe, as suggested by Putnam (1949, p. 1291).

Good preservation of the Sawmill Canyon moraines and their location on the present piedmont slope indicate that they are not as old as Sherwin. Patches of Sherwin till are preserved high on mountain-face interfluves both north and south of Walker Creek (Put-
(Fig. 1), photographed by Blackwelder (1931, p. 886, Fig. 12), suggests that the lower one may be of Mono Basin age.

Most students of Sierra Nevada glaciations have puzzled over the seeming lack of an Illinoian phase (Blackwelder, 1931, p. 918). Matthes (1930, p. 73) favored an Illinoian age for the El Portal glaciation of Yosemite Valley, but Blackwelder (1931, p. 908) correlated it with the Sherwin, which he regarded as Kansan. Recognition of the Mono Basin glaciation and the fact that its ice streams were less extensive than those of the subsequent Tahoe may explain this paradox. There is no proof that the Mono Basin glaciation is necessarily Illinoian, and such a correlation is at variance with other recent glacial and paleobotanical investigations in the Sierra Nevada. In a series of papers bearing upon the PlioPleistocene evolution of the Sierra Nevada, Axelrod and Ting (1960, p. 38-39; 1961, p. 141) and Axelrod (1962, p. 185, 187, 195-196) advocate that the McGee and Sherwin are respectively Kansan and Illinoian rather than Nebraskan and Kansan as suggested by Black- 
welder (1931, p. 918). Their conclusions are based primarily upon paleobotanical data but also involve tectonic and geomorphological relationships. The principal point of their argument is the lack of sufficient time between late Pliocene and a Nebraskan glaciation to allow for all the tectonic events and landscape evolution that must have occurred within that interval, according to their interpretation. On the basis of study at the type locality of the McGee till, Putnam (1960b, p. 273; 1962, p. $195,203,205)$ independently concludes that the McGee is Kansan rather than Nebraskan.

The position taken by these men is based on bold and imaginative arguments. It merits serious consideration. However, for the present we prefer for many reasons to regard it simply as a working hypothesis. Recent potassiumargon dates obtained on basalt flows resting on various erosion surfaces in the Sierra Nevada (Dalrymple, 1963, p. 384-387), if correct, are in direct conflict with the conclusions of Axelrod, Ting, and Putnam. Assignment of an Illinoian age to the Sherwin glaciation further increases the already bothercome discrepancy between the dating of Sierra glaciations and the $K^{40}-A^{40}$ age of 870,000 years ${ }^{2}$ of the Bishop tuff (Everndern and others, 1957). Putnam (1960a, p. 233-234, 237) regards the Bishop tuff as younger than Sherwin. Either this $\mathrm{K}^{40}-\mathrm{A}^{40}$ date or the interpretation of geological relationships at the Sherwin type locality are erroneous.

Characteristics of the respective deposits suggest that Blackwelder (1931, p. 881) had a good point in emphasizing the great length of time between Tahoe and Sherwin glaciations. Whether it was long enough to require that the Sherwin be Kansan is uncertain. The Mono Basin glaciation fits most easily with such an interpretation, as its features are distinctly older than Tahoe and considerably younger than Sherwin. The possibility that it represents a pre-Wisconsin but post-Illinoian glaciation such as postulated in other areas (Karlstrom, 1961, p. 295-301) does not merit much consideration until such a glaciation is better documented.

The Mono Basin glaciation is tentatively assigned to the Illinoian as that is where it fits best. This assignment is not based on direct or compelling evidence. It is compatible with Blackwelder's suggestion that the Sherwin is Kansan and the McGee is Nebraskan.

\footnotetext{
${ }^{2}$ Later work (Everndern, personal communication) suggests an age of 960,000 years for the Bishop tuff, further increasing the discrepancy.
}

\section{References Cited}

Axelrod, D. I., 1962, Post-Pliocene uplift of the Sierra Nevada, California: Geol. Soc. America Bull., v. 73, p. 183-198

Axelrod, D. I., and Ting, W. S., 1960, Late Pliocene floras east of the Sierra Nevada: Univ. Calif. Pub. Geol. Sci., v. 39, p. 1-118

- 1961, Early Pleistocene floras from the Chagoopa surface, southern Sierra Nevada: Univ. Calif. Pub. Geol. Sci., v. 39, p. 119-194

Birman, J. H., 1954, Pleistocene glaciation in the upper San Joaquin Basin, Sierra Nevada: Calif. Div. Mines Bull. 170, Chap. 5, p. 41-44

- 1959, Glacial geology on the eastern and western slopes, Sierra Nevada, California: Geol. Soc. America Bull., v. 70, p. 1709

-. in press, Glacial geology across the crest of the Sierra Nevada, California: Geol. Soc. America Special Paper

Blackwelder, Eliot, 1931, Pleistocene glaciation in the Sierra Nevada and Basin ranges: Geol. Soc. America Bull., v. 42, p. 865-922

Broecker, W. C., and Orr, P. C., 1958, Radiocarbon chronology of Lake Lahontan and Lake Bonneville: Geol. Soc. America Bull., v. 69, p. 1009-1032

Dalrymple, G. B., 1963, Potassium-argon dates of some Cenozoic volcanic rocks of the Sierra Nevada, California: Geol. Soc. America Bull., v. 74, p. 379-390

Evernden, J. F., Curtis, G. H., and Kistler, R., 1957: Potassium-argon dating of Pleistocene volcanics: Rome, Quaternaria, 4, p. 13-17

Frye, J. C., and Willman, H. B., 1960, Classification of the Wisconsin Stage in Lake Michigan glacial lobe: Illinois Geol. Survey Cir. 285, 16 p. 
Karlstrom, T. N. V., 1961, The glacial history of Alaska: Its bearing on paleoclimatic theory: New York Acad. Sci. Ann., v. 95, art. 1, p. 290-340

Kesseli, J. E., 1941, Quaternary history of Mono Valley, California: Univ. Calif. Pubs. Geography, v. 6, p. 315-362

Matthes, F. E., 1930, Geologic history of the Yosemite Valley: U. S. Geol. Survey Prof. Paper 160, $137 \mathrm{p}$.

McGee, W J, 1885, On the meridional deflection of ice streams: Am. Jour. Sci., v. 29, 3d ser., p. 386-392

Putnam, W. C., 1949, Quaternary geology of the June Lake district, California: Geol. Soc. America Bull., v. 60 , p. $1281-1302$

- 1960a, Origin of Rock Creek and Owens River gorges, Mono County, California: Univ. Calif. Pubs. Geol. Sci., v. 34, p. 221-280

- 1960b, Faulting and Pleistocene glaciation in the east-central Sierra Nevada of California, U.S.A.: Norden, Internat. Geol. Cong., 21st sess., pt. 21, p. 270-274

- 1962, Late Cenozorc geology of McGee Mountain, Mono County, California: Univ. Calif. Pubs. Geol. Sci., v. 40, p. 181-218

Russell, I. C., 1889, Quaternary history of Mono Valley, California: U. S. Geol. Survey 8th Ann. Rept., pt. 1, p. 261-394

Smith, G. I., 1962, Subsurface stratigraphy of late Quaternary deposits, Searles Lake, California, a summary: U. S. Geol. Survey Prof. Paper 450-c, p. c-65-68

Div. Geological Sciences, California Institute of Technology, Pasadena, Calif.; Dept. Geology, Occidental College, Los Angeles, Calif.

Manuscript Received by the Society, March 29, 1963

California Institute of Technology, Div. Geological Sciences Pub. No. 1143 